\title{
EROSIVE WEAR RESISTANCE OF SILICON \\ CARBIDE-CORDIERITE CERAMICS: INFLUENCE OF THE CORDIERITE CONTENT
}

\author{
ODPORNOST KERAMIKE SILICIJEV KARBID-KORDIERIT PROTI \\ OBRABI PRI EROZIJI: VPLIV VSEBNOSTI KORDIERITA
}

\author{
Milica Pošarac-Marković1, Djordje Veljović ${ }^{2}$ Aleksandar Devečerski ${ }^{1}$, \\ Branko Matović ${ }^{1}$, Tatjana Volkov-Husovic ${ }^{2}$ \\ 1University of Belgrade, Vinca Institute of Nuclear Sciences, P.O. Box 522, 11001 Belgrade, Serbia \\ ${ }^{2}$ University of Belgrade, Faculty of Technology and Metallurgy, Karnegijeva 4, POB 3503, Belgrade, Serbia \\ tatjana@tmf.bg.ac.rs
}

Prejem rokopisa - received: 2014-04-28; sprejem za objavo - accepted for publication: 2014-06-18

doi:10.17222/mit.2014.071

A cordierite/SiC composite was created in situ with reactive sintering at $1250{ }^{\circ} \mathrm{C}$ and $1300{ }^{\circ} \mathrm{C}$. The cordierite precursor was made from commercially available spinel, alumina and quartz and was mixed with the comercial SiC powder to obtain composite materials during the sintering. It was found that cordierite particles bind efficiently with the SiC powder during sintering and that reactive sintering is an effective way to produce ceramics at a relativly low temperature.

The goal of this investigation was to check the possibilities of using the silicon carbide-cordierite composite as a material resistant to the erosive wear. The fluid dynamic system of the experimental methodology was used here to produce ultrasonic erosive wear. Two kinds of SiC/cordierite samples were investigated, KS 50 and $\mathrm{KS} 30$, with different mass contents of cordierite $(w=50 \%$ and $w=30 \%$ of cordierite). The mass loss and the level of surface degradation were measured before and during the experiment. The level of surface degradation of the samples was monitored using the Image-Pro Plus program for the image analysis. It was found that after $150 \mathrm{~min}$ the mass loss was below $1.3 \mathrm{mg}$ and the surface degradation was below $7 \%$. The obtained results indicated that both samples exhibited an excellent erosion resistance during the cavitation experiment.

Keywords: ceramic-matrix composites (CMCs), damage tolerance, non-destructive testing, cavitation-erosion diameter and area

Kompozit kordierit-SiC je bil izdelan in-situ z reakcijskim sintranjem pri $1250{ }^{\circ} \mathrm{C}$ in $1300{ }^{\circ} \mathrm{C}$. Kordieritna predoblika, izdelana iz komercialno dostopnega špinela, aluminijevega oksida in kremena, je bila zmešana s prahom komercialnega SiC, da bi dobili s sintranjem kompozitni material. Ugotovljeno je, da delci kordierita učinkovito vežejo SiC-prah med sintranjem in da je reakcijsko sintranje učinkovita metoda za izdelavo keramike pri relativno nizki temperaturi.

Cilj te raziskave je preveriti možnost uporabe SiC-kordieritnega materiala, odpornega proti obrabi z erozijo. Za ultrazvočno erozijsko obrabo je bila uporabljena eksperimentalna metoda fluidnega dinamičnega sistema. Preiskovani sta bili dve vrsti vzorcev SiC-kordierit, KS 50 in KS 30, z različnima masnima vsebnostima kordierita ( $w=50 \%$ in $w=30 \%$ kordierita). Masni delež obrabe površine je bil izmerjen pred preizkusom in po njem. Stopnja degradacije površine vzorcev je bila ugotovljena s programom za analizo slik Image Pro Plus. Ugotovljeno je bilo, da je bila izgube mase po 150 min manjša od $1,3 \mathrm{mg}$ in degradacija površine manjša od $7 \%$. Dobljeni rezultati kažejo, da imata med preizkusom kavitacije oba vzorca odlično odpornost proti eroziji.

Ključne besede: kompozit s keramično osnovo (CMCs), toleranca poškodb, neporušne preiskave, premer in površina erozije pri kavitaciji

\section{INTRODUCTION}

Ceramic materials have been used for centuries as the materials with a very wide range of mechanical and thermal properties suitable for various applications. Today, their common industrial use is more related to the electronics for mechanical parts and biomedicine applications (hip prosthesis, dental implants). One of the main reasons for this is the improvement of the fracture toughness that allows a ceramic material to perform better when it is subjected to the operating conditions. Sometimes these operating conditions may involve rapid changes in the temperature, or a high-temperature application as well as the conditions that include cavitation erosion. This could be related to the technical ceramics, for example, the operations of bearings, injectors or valves. Cavitation, i.e., the appearance of vapor cavities inside an initially homogeneous liquid medium, occurs in very different situations. Hence, the study of the cavitation and cavitation-erosion mechanisms of technical ceramics is of importance to improve their performance in real applications. ${ }^{1-4}$

Metallic materials are the most common choice when cavitation-erosion resistance is required. Research results concerning the applications of different classes of materials, including ceramics and composite materials for a similar use, were published in the last decade. ${ }^{1-10}$ Different types of ceramics based on silicon nitride and zirconia, as well as alumina-based ceramic materials were investigated in the conditions of cavitation erosion..$^{2,4-9}$ In numerous papers ${ }^{1-12}$ related to the investigations of the erosion rate of these materials, attempts were made to 
investigate the type of cracking as well as the influence of the grain sizes and the contents of different compounds and phases on the resistance of the materials to the erosive wear.

The goal of our investigation was to study the possibilities of using a silicon carbide/cordierite based ceramic material as a potential cavitation-resistant material.

\section{MATERIALS}

The properties of cordierite/silicon carbide based ceramics that enable a widespread use in high-temperature conditions are a particularly low coefficient of thermal expansion, a high thermal conductivity, an excellent thermal fire resistance and an excellent resistance to a thermal shock. Their target application is in the furnaces for the use at the temperatures of over $1000{ }^{\circ} \mathrm{C}$. An addition of silicon carbide improves the physical and mechanical properties of refractory cordierite. The high thermal conductivity of silicon carbide reduces the thermal stresses within a cordierite ceramic body. A mixture of commercially available spinel $\left(\mathrm{MgAl}_{2} \mathrm{O}_{4}\right)$, quartz $\left(\mathrm{SiO}_{2}\right)$ and alumina $\left(\mathrm{Al}_{2} \mathrm{O}_{3}\right)$ corres-
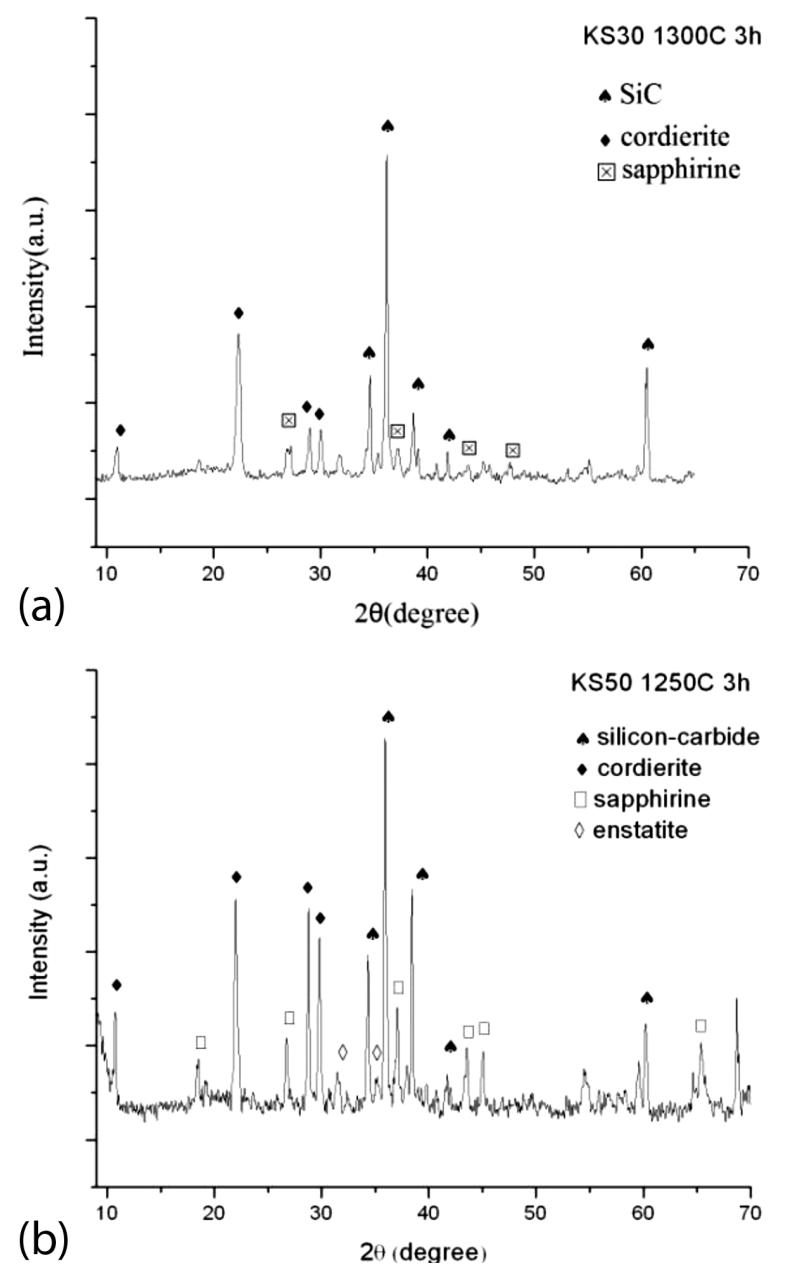

Figure 1: XRD of the: a) KS 30 and b) KS 50 samples Slika 1: XRD-posnetka vzorcev: a) KS 30 in b) KS 50 ponding to a cordierite stoichiometric composition was attrition milled using $\mathrm{Al}_{2} \mathrm{O}_{3}$ balls and ethyl alcohol as the media for four hours; henceforth, this mixture was labeled as KS. Mixture KS was used for preparing the cordierite/SiC composite ceramics with the mass ratio of $30: 70$ and $50: 50$, respectively. After the milling with the $\mathrm{Al}_{2} \mathrm{O}_{3}$ balls in DI water in a polyethylene bottle for 24 $\mathrm{h}$, the samples were uniaxially pressed and sintered at $1300{ }^{\circ} \mathrm{C}$ and $1250{ }^{\circ} \mathrm{C}$, for $3 \mathrm{~h}$, and the ceramic composite samples were marked as KS 30 and KS 50, respectively. The typical values of the selected properties of the dense constituents used in the refractory materials investigated are listed in the previous papers. ${ }^{13-15}$

An XRD analysis of the KS 30 sample (Figure 1) shows a presence of three crystalline phases: $\mathrm{SiC}$, cordierite and sapphirine and a presence of a certain amount of a glassy phase. In the case of sample KS 50, the phase analysis shows a presence of four crystalline phases: $\mathrm{SiC}$, cordierite, sapphirine and enstatite. There is also a small amount of a glassy phase, which affects the formation of cordierite and sapphirine. One can conclude that an increase in the added amount of the mixture with a composition corresponding to stoichiometric cordierite improves the quantity and crystallization of cordierite.

The microstructures of samples KS 30 and KS 50 (Figure 2) were examined with scanning electron micro-
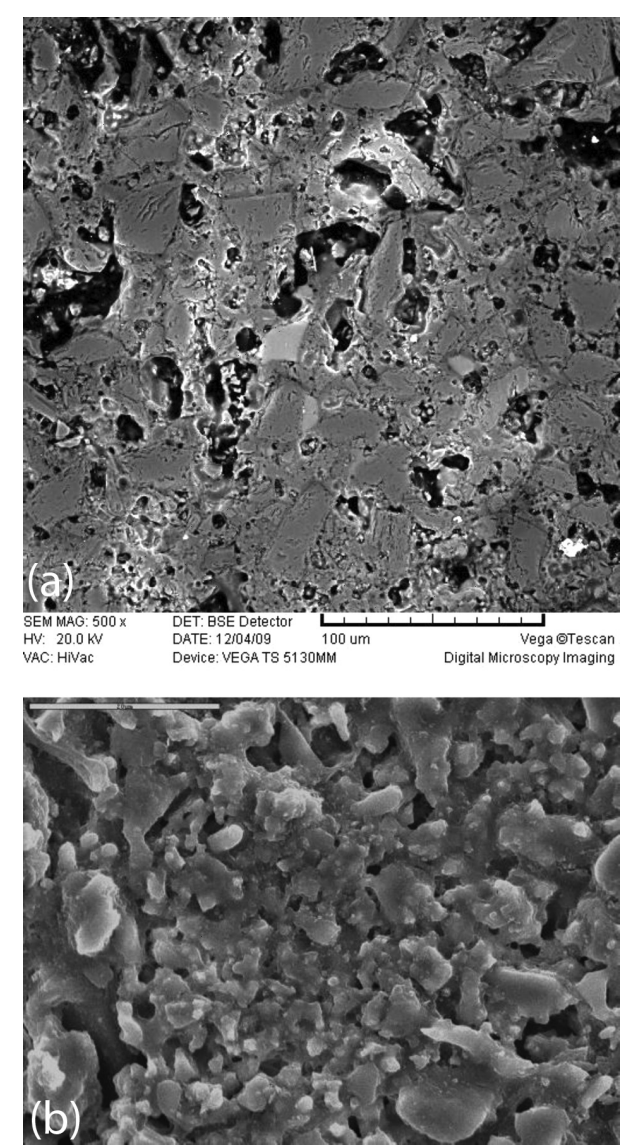

Figure 2: SEM of the: a) KS 30 and b) KS 50 samples Slika 2: SEM-posnetka vzorcev: a) KS 30 in b) KS 50 
scopy using a VEGA TS 5130 mm (TESCAN) device; the samples were coated with a layer of the Au-Pd mixture. A porous structure was observed, with the particles of different sizes and pronounced necks formed during the densification. The pores that are not spherical indicate the initial stages of sintering. The pores present have different sizes and shapes.

\section{CAVITATION-EROSION TESTING}

The experimental methodology used for the cavitation-erosion testing is explained in $^{7,10,16,17}$. With respect to the used equipment, the diameter of the horn was 10 $\mathrm{mm}$ and the distance between the horn and a sample was $1 \mathrm{~mm}$. The samples were discs with a diameter of $3 \mathrm{~cm}$ and a height of $1 \mathrm{~cm}$.

\section{RESULTS AND DISCUSSION}

\subsection{Mass loss and level of destruction during the testing}

The mass losses of the test specimens were determined using the analytical balance with an accuracy of $\pm 0.1 \mathrm{mg}$. The measurements were performed after subjecting each test specimen to cavitation for $30 \mathrm{~min}$. The duration of the tests was $150 \mathrm{~min}$. The light microscopy technique was applied to analyze the effect of the erosion and to interpret the results of the cavitation tests (Figure 3).

The mass loss was below $1.3 \mathrm{mg}$, which is similar to metallic $^{15-25}$ and ceramic ${ }^{5,6,24,25}$ materials. From Figure 2 it can be seen that sample KS 30 exhibited a better resistance to erosive wear, as after $150 \mathrm{~min}$ the mass loss for KS 30 was $0.12 \mathrm{mg}$ and for KS 50 it was $1.23 \mathrm{mg}$.

The next experiment consisted of the measurements of the degradation levels before and during the testing. In order to carry out an image analysis determining the level of destruction before and during the testing, the samples were photographed as shown in Figure 4.

The results of the image analysis of samples KS 50 and KS 30 are given in Figure 5.

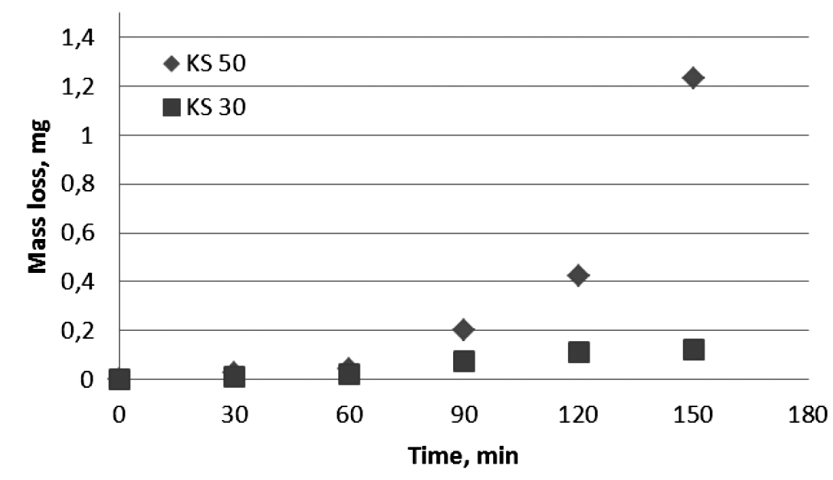

Figure 3: Mass loss during the experiment Slika 3: Izguba mase med preizkusom

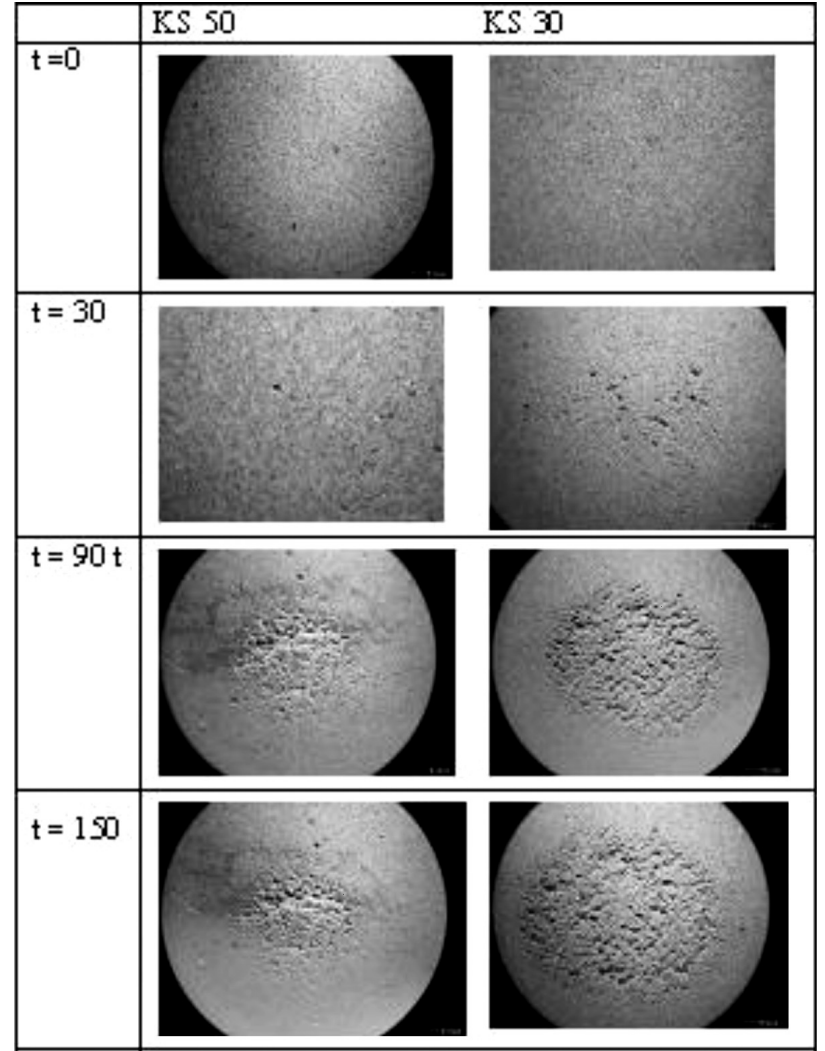

Figure 4: Photographs of the samples during the testing Slika 4: Posnetki vzorcev med preizkusi

Based on the obtained results, similar conclusions regarding the level of degradation and the mass loss of the samples can be given. Samples KS 50 exhibited a better erosion resistance as their level of damage was $4.4 \%$ compared to $6.9 \%$ for the KS 30 samples. The differences in the sample behavior can be related to the crack nucleation and propagation during the cavitation testing.

As can be seen from Figure 5, samples KS 50 exhibited a stable increase in the level of degradation and similar rates of degradation for the entire time range. At

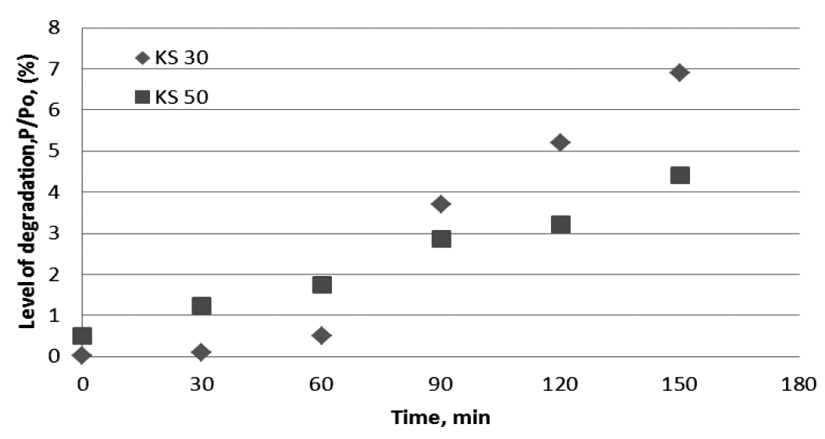

Figure 5: Level of destruction of the samples $\left(P / P_{\mathrm{o}}\right)$ versus the time of experiment $\left(P\right.$ is the damaged area after the testing and $P_{\mathrm{o}}$ is the undamaged area)

Slika 5: Nivo propada vzorcev $\left(P / P_{\mathrm{o}}\right)$ v odvisnosti od časa preizkusa, ( $P$ je poškodovano področje po preizkusu in $P_{\mathrm{o}}$ je nepoškodovano področje) 
the end of the experiment, after $150 \mathrm{~min}$, the level of degradation was below $5 \%$.

For the KS 30 samples, two regimes can be observed on Figure 5. The first regime is characterized by a slow increase in the level of destruction over the period from 0 $\min$ to $60 \mathrm{~min}$. The second regime, after $60 \mathrm{~min}$ of the testing, is characterized by a more rapid change in the damage level. However, it has to be mentioned that the total level of degradation, after $150 \mathrm{~min}$ of the testing, did not exceed $8 \%$, which is an excellent result for the cavitation resistance.

From these results it can be concluded that samples KS 30 have a better resistance to crack nucleation and propagation up to the 60th minute of the experiment. After this critical time, the crack propagation is very rapid. The increased cordierite amount and decreased $\mathrm{SiC}$ amount influenced the crack nucleation and propagation, as the higher values of cordierite in samples KS 50 caused lower rates of crack propagation during the entire time (0-150 $\mathrm{min})$ and the total degradation of the samples after $150 \mathrm{~min}$ of the testing was lower.

\subsection{Erosion-ring diameter and erosion-ring area}

The samples exposed to cavitation erosion (Figure 3) were also monitored in order to measure the diameters and the areas of the erosion-ring regions. These measurements were performed using the following steps:

Step 1: Making appropriate micrographs that include the erosion ring areas (Figure $\mathbf{3}$ )

Step 2: Measuring the ring diameters: at this point two types of measurements were taken: diameters $\left(d_{1}\right)$ and $\left(d_{2}\right)$ of the cavitation-ring erosion measured with the Image-Pro Plus program. The effective diameter of each ring is calculated according to the following equation:

$$
d=\frac{d_{1}+d_{2}}{2}
$$

Step 3: Calculating the effective area of the erosion ring using the values of the diameters measured in Step 2:

$$
P_{\mathrm{av}}=\frac{\pi d_{1} d_{2}}{4}
$$

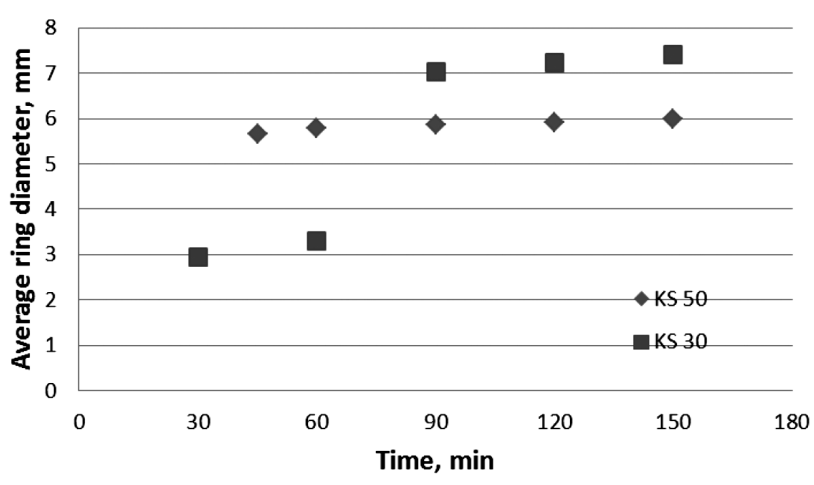

Figure 6: Average diameter of the erosion ring during the testing Slika 6: Povprečni premer erozijskega kroga med preizkušanjem
Step 4: Using the Image-Pro Plus program to determine the average erosion-surface area of the ring, $\left(P_{\text {meas }}\right)$.

\subsection{Erosion-ring measuremets}

The measurements of the average diameter of the erosion ring were made after $(30,45,60,90,120$ and 150) $\min$.

Samples KS 50: The results presented in Figure 6 show that the formation of an erosion ring can be observed after $45 \mathrm{~min}$ of the testing. The average erosionring diameter increased from $5.68 \mathrm{~mm}$ after $45 \mathrm{~min}$ to $6.03 \mathrm{~mm}$ after $150 \mathrm{~min}$ of the testing.

Samples KS 30: The errosion-ring formation of this sample was observed after $30 \mathrm{~min}$. A rapid increase in the ring diameter was observed after $90 \mathrm{~min}$, when the ring diameter increased from $3.29 \mathrm{~mm}$ after $60 \mathrm{~min}$ to $7.04 \mathrm{~mm}$ after $90 \mathrm{~min}$ of the testing. After $90 \mathrm{~min}$ the increase in the ring diameter was very slow so that after $150 \mathrm{~min}$ the ring diameter reached only $7.41 \mathrm{~mm}$.

The results for the erosion-ring measuremet are in a strong correlation with the results for the level of destruction (Figure 5) supporting the conclusions about the influence of cordierite and SiC content on the level of degraration. The same conlusions are valid if the erosion-ring measurements are taken into account. With respect to the energy for crack nucleation, lower values are expected for the KS 30 samples where the formation of the erosion ring was observed after $30 \mathrm{~min}$, while for the KS 50 samples it was formed after $45 \mathrm{~min}$. This difference could be important for some specific applica-
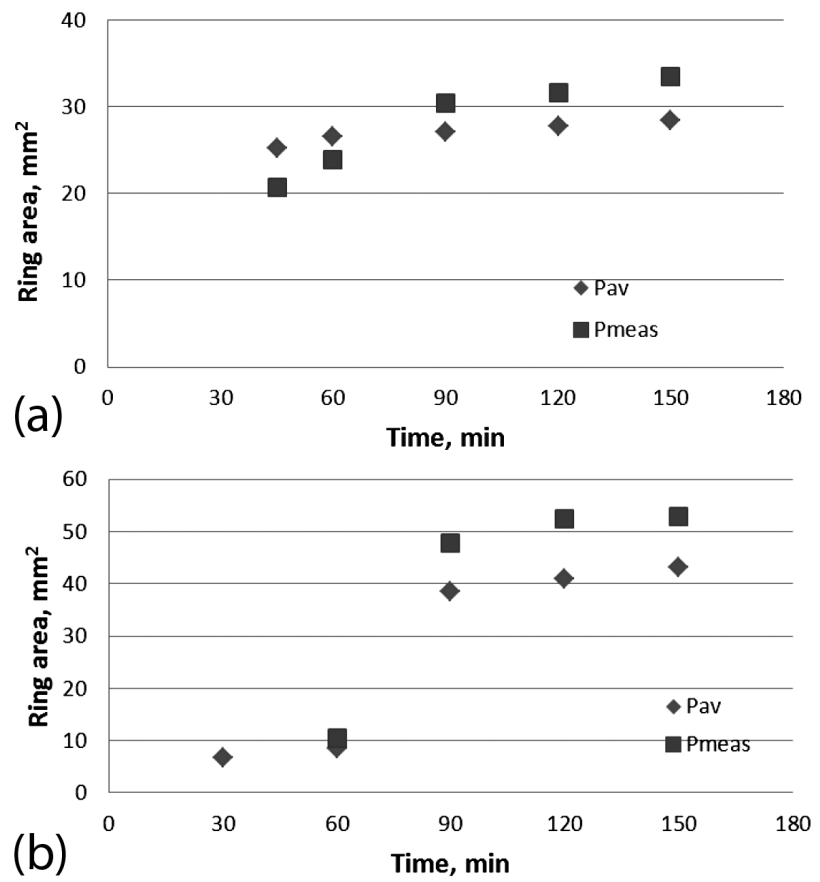

Figure 7: Average area of the erosion ring based on diameter measurements and area measurements: a) KS 50 and b) KS 30

Slika 7: Povprečna površina erozijskega kroga na podlagi meritev premera in površine: a) KS 50 in b) KS 30 
tions where the specific resistance to either crack nucleation or crack propagation is requested.

\subsection{Average erosion-surface area}

According to the procedure described above, Figure 7 shows the values obtained for the average erosion-surface areas based on monitoring the erosion-ring diameters.

Samples KS 50: The formation of the erosion ring was detected after 45 minutes and the average erosionsurface area was $P_{\text {meas }}=20.73 \mathrm{~mm}^{2}$ and $P_{\mathrm{av}}=25.23 \mathrm{~mm}^{2}$. Both values for the erosion ring area were slowly increased, reaching the values of $P_{\mathrm{av}}=28.35 \mathrm{~mm}^{2}$ and $P_{\text {meas }}=33.42 \mathrm{~mm}^{2}$ after $150 \mathrm{~min}$ of the testing. The results showed the differences caused by implementing the method for the erosion-ring-area determination (during the above steps) and these differences apply to the whole experiment.

Samples KS 30: As for the ring-diameter measurements, after $60 \mathrm{~min}$ of the testing the erosion ring was detected, with the erosion-surface area of $P_{\text {meas }}=10.56$ $\mathrm{mm}^{2}$ and $P_{\mathrm{av}}=8.49 \mathrm{~mm}^{2}$. After $90 \mathrm{~min}$ a rapid change in the erosion area was observed so that after $150 \mathrm{~min}$ of the testing the erosion-surface values raised to $P_{\mathrm{av}}=$ $43.76 \mathrm{~mm}^{2}$ and $P_{\text {meas }}=52.81 \mathrm{~mm}^{2}$. The differences in the values obtained with step $4\left(P_{\text {av }}\right)$ and step $5\left(P_{\text {meas }}\right)$ were increasing during the experiment.

Based on the obtained results it can be concluded that samples KS 30 are more sensitive to the formation of the erosion ring. Also, after $90 \mathrm{~min}$ of the testing there are rapid changes in the diameter and the surface of the erosion ring, but by the end of the testing $(150 \mathrm{~min})$ this increase is slowed down.

Samples KS 50 exhibited a better erosion resistance as the ring diameter and the average area of erosion were lower, and their increase was slower over the testing time.

The formation of the erosion ring for the KS 50 samples is visible after $30 \mathrm{~min}$. This can be related to the influence of the crack nucleation caused by the erosion experiment.

\section{CONCLUSION}

Ceramic composite samples based on the SiC/cordierite ceramic material were synthesized in order to investigate the sample resistance to the erosive wear. Two samples with different mass contents of cordierite and $\mathrm{SiC}$ were used in this investigation: KS $50(w=50 \%$ of cordierite) and $\mathrm{KS} 30$ ( $w=30 \%$ of cordierite).

The results for the mass loss as well as for the level of degradation indicate a similar (or even better) erosion resistance compared to the metallic and low-alumina samples.

Both samples exhibited an excellent erosive resistance, but sample KS 50 exhibited the better resistance of the two as its mass loss was lower, as were the level of degradation, the erosion-ring diameter and the erosion area.

These experiments showed that composite ceramic materials based on $\mathrm{SiC} /$ cordierite can be used as erosion-resistant materials, used for new applications.

Also, an implementation of non-destructive testing such as an image analysis to determine the erosion-ring diameter and the erosion-ring area improved the reliability of predicting the sample behavior in the conditions of erosive wear.

\section{Acknowledgement}

This research was financed by the Ministry of Education, Science and Technological Development of Serbia as part of project III 45012.

\section{REFERENCES}

${ }^{1}$ W. J. Tomlinson, S. J. Matthews, Cavitation erosion of structural ceramics, Ceramics International, 20 (1994), 201-209, doi:10.1016/ 0272-8842(94)90040-X

${ }^{2}$ U. Litzow, K. H. Z. Gahr, J. Schneider, Cavitation erosion of advanced ceramics in water, International Journal of Materials Research: Zeitschrift für Metallkunde, 97 (2006), 1372-1377, doi:10.3139/146.101380

${ }^{3}$ D. Niebuhr, Cavitation erosion behavior of ceramics in aqueous solutions, Wear, 263 (2007), 295-300, doi:10.1016/j.wear.2006.12.040

${ }^{4}$ G. Garcia-Atance Fatjó, M. Hadfield, K. Tabeshfar, Pseudoplastic deformation pits on polished ceramics due to cavitation erosion, Ceramics International, 37 (2011), 1919-1927, doi:10.1016/ j.ceramint.2011.03.043

${ }^{5}$ S. Martinovic, M. Dojcinovic, J. Majstorovic, A. Devecerski, B. Matovic, T. Volkov Husovic, Implementation of image analysis on thermal shock and cavitation resistance testing of refractory concrete, Journal of European Ceramic Society, 30 (2010), 3303-3309, doi:10.1016/j.jeurceramsoc.2010.07.041

${ }^{6}$ S. Martinovic, M. Vlahovic, M. Dojcinovic, T. Volkov-Husovic, J. Majstorovic, Thermomechanical properties and cavitation resistance of a high-alumina low-cement castable, International Journal of Applied Ceramic Technology, 8 (2011) 5, 1115-1124, doi:10.1111/ j.1744-7402.2010.02545.x

${ }^{7}$ G. Garcia-Atance Fatjó, M. Hadfield, C. Vieillard, J. Sekulic, Early stage cavitation erosion within ceramics - an experimental investigation, Ceramics International, 35 (2009), 3301-3312, doi:10.1016/ j.ceramint.2009.05.020

${ }^{8}$ M. H. Korkut, Y. Küçük, A. C. Karaoğlanli, A. Erdoğan,Y. Er, M. S. Gök, Effect of the abrasive grit size on the wear behavior of ceramic coatings during micro-abrasion test, Mater. Tehnol., 47 (2013) 6, 695-699

${ }^{9}$ J. Bažan, L. Socha, L. Martínek, P. Fila, M. Balcar, J. Chmelař, Wear of refractory materials for ceramic filters of different porosity in contact with hot metal, Mater. Tehnol., 45 (2011) 6, 603-608

${ }^{10}$ G. Garciá-Atance Fatjó, A. Torres Pérez, M. Hadfield, Experimental study and analytical model of the cavitation ring region with small diameter ultrasonic horn, Ultrasonics Sonochemistry, 18 (2011), 73-79, doi:10.1016/j.ultsonch.2009.12.006

${ }^{11}$ F. G. Hammit, Cavitation and Multiphase Flow Phenomena, McGraw-Hill, New York 1980

${ }^{12}$ R. T. Knapp, J. W. Daily, F. G. Hammit, Cavitation, McGraw-Hill, New York 1970

${ }^{13}$ M. Posarac, M. Dimitrijevic, T. Volkov-Husovic, A. Devecerski, B. Matovic, Determination of thermal shock resistance of silicon carbide/cordierite composite material using nondestructive test methods, Journal of the European Ceramic Society, 28 (2008) 6, 1275-1278, doi:10.1016/j.jeurceramsoc.2007.09.038 
${ }^{14}$ M. Dimitrijevic, M. Posarac, J. Majstorovic, T. Volkov-Husovic, B. Matovic, Behavior of silicon carbide/cordierite composite material after cyclic thermal shock, Ceramics International, 35 (2009) 3, 1077-1081, doi:10.1016/j.ceramint.2008.04.029

${ }^{15}$ M. Posarac-Markovic, Ph.D. Thesis, University of Belgrade, Faculty of Technology and Metallurgy (in Serbian)

${ }^{16}$ T. Okada, S. Hattori, M. Shimizu, A fundamental study of cavitation erosion using a magnesium oxide single crystal (intensity and distribution of bubble collapse impact loads), Wear, 186-187 (1995), 437-443, doi:10.1016/0043-1648(95)07162-8

${ }^{17}$ S. Hattori, H. Mori, T. Okada, J. Fluid Eng, Trans. ASME, 120 (1998), 179-185, doi:10.1115/1.2819644

${ }^{18}$ T. Okada, S. Hattori, Proc. of the Int. Symposium on Aerospace and Fluid Science, Sendai, Japan, 1993, 347

${ }^{19}$ K. Steller, Proc. of the 6th Int. Conf. on Erosion by Liquid and Solid Impact, Cambridge, UK, 1983, 121

${ }^{20}$ G. Bregliozzia, A. Di Schinob, S. I. U. Ahmeda, J. M. Kennyb, H. Haefkea, Wear, 258 (2005), 503-510, doi:10.1016/j.wear.2004. 03.024
${ }^{21}$ W. J. Tomlinson, A. S. Bransden, Wear, 185 (1995), 59-65, doi:10.1016/0043-1648(94)06584-5

${ }^{22}$ C. J. Lin, J. L. He, Wear, 259 (2005), 154-159, doi:10.1016/j.wear. 2005.02.099

${ }^{23}$ M. Dojcinovic, T. Volkov Husovic, Cavitation damage of the medium carbon steel: impelmentation of image anaysis, Materials Letters, 62 (2008), 953-956, doi:10.1016/j.matlet.2007.07.019

${ }^{24}$ S. Martinovic, M. Dojcinovic, J. Majstorovic, A. Devecerski, B. Matovic, T. Volkov Husovic, Implementation of image analysis on thermal shock and cavitation resistance testing of refractory concrete, Journal of European Ceramic Society, 30 (2010), 3303-3309, doi:10.1016/j.jeurceramsoc.2010.07.041

${ }^{25}$ S. Martinovic, M. Vlahovic, M. Dojcinovic, T. Volkov-Husovic, J. Majstorovic, Thermomechanical properties and cavitation resistance of a high-alumina low-cement castable, International Journal of Applied Ceramic Technology, 8 (2011) 5, 1115-1124, doi:10.1111/ j.1744-7402.2010.02545.x 